\title{
HIPPOCRATES: FACTS AND FICTION
}

\begin{abstract}
Hippocrates, the Father of Medicine, is reviewed as a historical person and in terms of his contribution to medicine in order to distinguish fact from fiction. Contemporary and later sources reveal that many (possibly untrue) legends accumulated around this enigmatic figure. The textual tradition and the composition of the socalled Corpus Hippocraticum, the collection of medical works written mainly in the $5^{\text {th }}$ and $4^{\text {th }}$ centuries BC (of which possibly only about five can be ascribed to Hippocrates himself) are discussed. The origin of the Hippocratic Oath, and the impact of the Hippocratic legacy on modern medicine are considered.
\end{abstract}

\section{INTRODUCTION}

This article considers the historicity of Hippocrates, the Father of Medicine, distinguishes fact from fiction and assesses his contribution to the discipline in the context of the many myths, which are shown by both contemporary and later sources to have arisen about this enigmatic figure. The textual transmission and compilation of the Corpus Hippocraticum, a collection of medical texts written mainly in the $5^{\text {th }}$ and $4^{\text {th }}$ centuries $\mathrm{BC}$ (of which only perhaps five can be ascribed to Hippocrates with any degree of certainty), will also be discussed. Finally, the origin of the Hippocratic Oath and the value of the Hippocratic legacy to modern medicine will be examined.

Hippocrates has enjoyed unrivalled acclaim as the Father of Medicine for two and a half millennia. Yet he is also an enigmatic figure, and there is much uncertainty about his life and his true contribution to medicine. His contemporaries mention him without adulation in their writings, but within a few centuries of his death he was a legendary figure. What is more, the collection of medical writings named after him, the Corpus Hippocraticum, remained the basis of rational medicine for over 2000 years. However, in 1931 the renowned medical historian Ludwig Edelstein (1967a) stated that although Hippocrates was indeed a historical figure, there is no evidence to indicate that he was responsible for writing all the treatises constituting the Corpus Hippocraticum, or even part of it. 
Hippocrates: facts and fiction

\section{HISTORICAL SOURCES}

\subsection{Contemporaries}

Certain writings from the $5^{\text {th }}$ and $4^{\text {th }}$ centuries BC mention Hippocrates. An early dialogue of Plato's, the Protagoras (par. 311B) describes him as the famous physician of Cos. In a later dialogue, the Phaedrus (par. 270C), Hippocrates is again mentioned as a member of the Asclepiadae family. Forty years later, Aristotle refers to him as the wise physician in his Politics (1326 $15-17)$. A relative of Hippocrates, the $4^{\text {th }}$ century physician Ctesias of Cnidus, writes critically of some of his medical procedures (Gillespie 1972:419). And in a much later document there is a reference to Menon, a pupil of Aristotle, who identifies Hippocrates as the author of Breaths, a text which forms part of the Corpus Hippocraticum (Gillespie 1972:481).

\subsection{Later sources}

Later sources of information on Hippocrates's life and contribution to medicine, written in the centuries after his death, include the medical texts of Diocles of Caristus (arguably the best physician of the $4^{\text {th }}$ century BC), the De re rustica (1.4.5) by Varro ( $1^{\text {st }}$ century BC), and a tract entitled The best doctor is also a philosopher (cc. 1-4) by Galen, the famous doctor/philosopher/author of the $2^{\text {nd }}$ century AD. Four biographies are also extant (Pinault 1992:24-28), but their historical accuracy is doubtful since they are based on oral tradition.

i. The oldest and most complete biography was compiled by Soranus, probably referring to the famous physician of Ephesus, in the $2^{\text {nd }}$ century AD (thus some 700 years after Hippocrates's life). This is the main source used by other biographers.

ii. The $10^{\text {th }}$ century encyclopaedia, the Suidas, contains a biography.

iii. There is also a $12^{\text {th }}$ century biography in verse by the Byzantine scholar John Tzetzes.

iv. Another $12^{\text {th }}$ century biography is anonymous, but probably based on a $5^{\text {th }}$ century original, the "Brussels manuscript".

Various historical texts in the Corpus Hippocraticum also give details of aspects of Hippocrates's life, but these are later additions and lar- 
gely mythical. There are also some biographical works from the Islamic era ( $7^{\text {th }}$ to $13^{\text {th }}$ century), written by admirers of Hippocrates such as as-Sijistari and Fatik (Pinault 1992:95-102).

\section{BIOGRAPHY}

As has been indicated, there are few certain facts and many myths about the life of Hippocrates. The sketch which follows is based on what is generally recognised by scholars today as probably true.

Hippocrates was born on the island of Cos in 460 BC (probably on August 27). His parents were Heraklides and Phenaretis. He was a member of the Asclepiadae family, which had a history of medical practice and was traditionally believed to be descended from Asclepius. Hippocrates was trained within the family as a physician and began to practice on Cos. His wife's name is unknown, but she came from a prominent family. They had two sons, Thessalus and Draco (both of whom trained as physicians), and a daughter who married Polybus, one of Hippocrates's students who later also became famous as a physician (Jouanna 1999:19).

According to Soranus's biography, Hippocrates was quite short in stature and lost his hair in old age. Effigies and portraits on coins confirm this, also showing him bearded (Jouanna 1999:39; Levine 1954:18).

He was involved in the training of physicians on the island of Cos, but no archaeological remains survive from this era. He lived on the western side of the island, in Astupalaea (literally, the Old City), while the oldest ruins indicative of medical training date from the $4^{\text {th }}$ century $\mathrm{AD}$ and are located on the eastern side. In the centre of the modern town of Cos there stands a giant plane tree in whose shade Hippocrates is traditionally supposed to have taught his students, but the tree is probably not older than 500 years. South of Cos and separated from it by a narrow strait lies the peninsula of Cnidos, which had a well-known centre for medical training in Hippocrates's day. According to Galen's commentary on the Hippocratic text On joints (4.40), there was lively and healthy competition between the two institutions, whose medicophilosophical premises were almost identical. Cos later became famous on account of the Corpus Hippocraticum, although it was not written exclusively there. Cnidos also left a written legacy, the "Cnidian sayings", 
Hippocrates: facts and fiction

while parts of the Corpus Hippocraticum itself are also of Cnidian origin (Gillespie 1972:420; Jouanna 1999:49). The story that Hippocrates had the archives on Cnidos razed to the ground is devoid of all truth (Jouanna 1999:49-50).

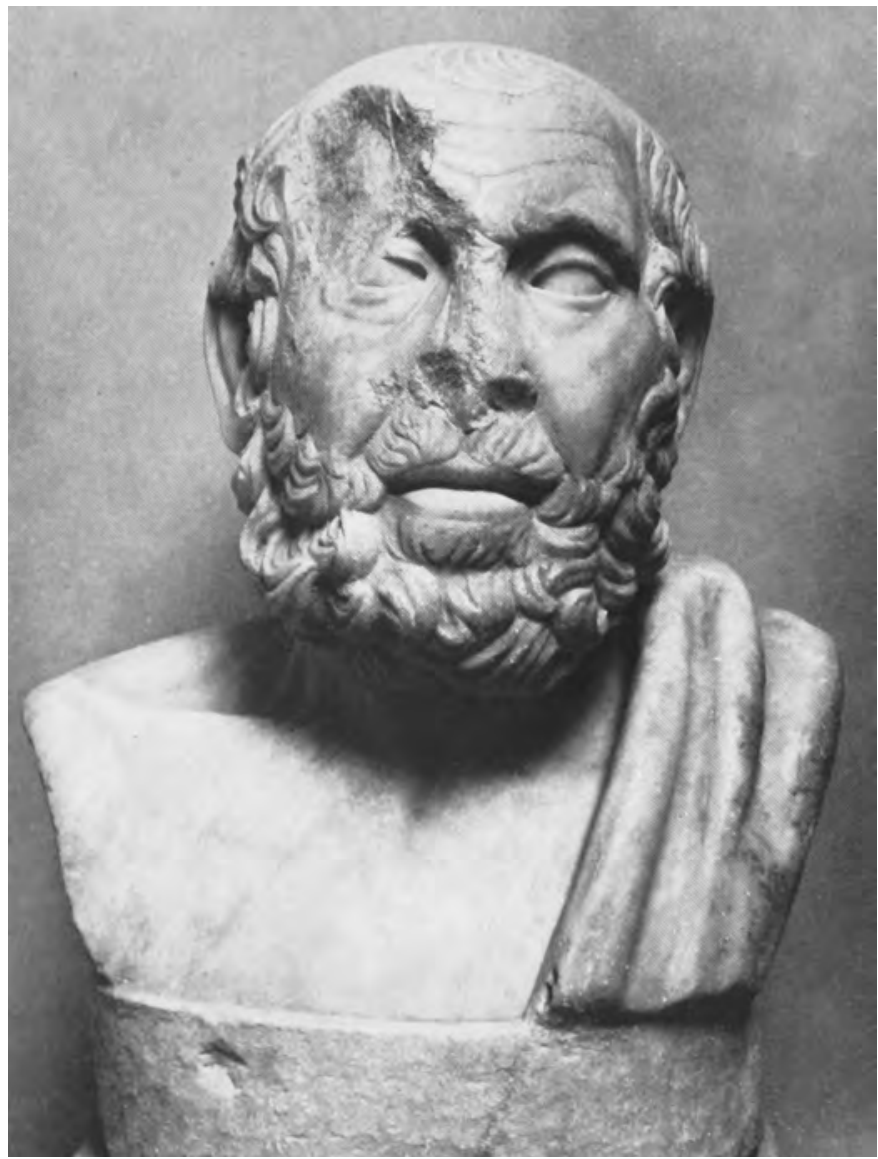

Figure 1: Hippocrates. Bust found at Ostia, Italy, standing on a pedestal bearing the Hippocratic Oath. Ostia Museum. 
It would appear that in Hippocrates's time medical training on Cos began to be extended beyond the exclusive circle of physicians' descendants. At least ten named pupils were not of the Asclepiadae family, and some even came from further afield than Cos. Among these, Dexippus, Apollonius and Praxagoras the Elder later became renowned. Training was offered at a fixed rate, and Hippocrates's name apparently lent a great cachet to the school, but we have little detail on this subject (Levine 1954:15; Lloyd 1983a:37).

After the deaths of his parents (probably between 430 and $420 \mathrm{BC}$ ), Hippocrates left Cos and moved to Thessaly on the Greek mainland. Polybus, his son-in-law, was appointed as his successor, and all indications are that the medical school at Cos continued to enjoy a good reputation even into the Hellenistic period when the school at Alexandria became prominent. In his new home, Hippocrates continued to offer medical services and training for at least 50 years. We do not know whether he was a physician in public service or employed privately by the aristocracy, but it is surmised that he travelled often and extensively, since the addresses of patients mentioned in the treatise Epidemics include places in Northern Greece, Thrace, Macedonia and even further afield. Incidentally, Jouanna (1999:56-57) suggests that the use of the first-person plural form in many of these reports on patients may indicate that Hippocratic physicians often travelled in groups.

Most of the clinical work in the Corpus Hippocraticum probably dates from this period, but it also produced most of the popular, probably untrue, myths about Hippocrates, including those which follow.

i. His visit to Perdiccas, the king of Macedonia, whom he had to cure of what appeared to be tuberculosis, but was actually the physical effects of frustration in love (Pinault 1992:125-126).

ii. His refusal to help King Artaxerxes I to combat an epidemic in Persia, because, as a loyal Greek, Hippocrates could not assist the Persian enemy (Pinault 1992:125-126).

iii. His handling of requests for aid in treating epidemics among enemies in the northern areas: again he is said to have refused assistance but to have warned the Greeks to prepare themselves to face these diseases (Pinault 1992:125-126). This was in the years 419- 
Hippocrates: facts and fiction

$416 \mathrm{BC}$, and must be distinguished from the myth that he cured the Athenian epidemic of 430-426 BC (Jouanna 1999:30-34).

iv. His diplomatic representations to Athens and Thessaly to oppose the plundering of Cos (Jouanna 1999:30-34).

v. Later Arabian legends that he assisted the Ptolemaic kings of Egypt and even the Persian king, Artaxerxes, and that he had a tragic love-affair with a Gallic girl — fictions which border on the bizarre (Pinault 1992:125-126).

vi. The story that he visited Delphi on behalf of the Asclepiadae family and negotiated special privileges with the oracle - a tale which may contain an element of truth (Jouanna 1999:30-34).

Along with his merits as a physician, all these stories attempt to celebrate Hippocrates's virtues, such as loyalty and statesmanship, as well as national pride.

Hippocrates never returned to Cos, and is buried in Larissa, in Thessaly. His date of death is unknown; estimates range from 375 to 351 $\mathrm{BC}$, which means that he would have died at an age between 85 and 109 (Jouanna 1999:36).

\section{THE CORPUS HIPPOCRATICUM}

\subsection{Textual transmission}

The 60 or 70 texts which were collated as the Corpus Hippocraticum have traditionally been taken to represent Hippocrates's written legacy to posterity. However, it is highly unlikely that any one person could have written the Corpus: the texts are heterogeneous in terms of writing style and content, as well as being self-contradictory in places. Although the majority of them are medical, there are also historical and biographical works. Several of the texts have been accepted as dating from the time of Hippocrates or shortly thereafter $\left(5^{\text {th }}\right.$ and $4^{\text {th }}$ centuries BC), and as being written either by Hippocrates or by physicians within his sphere of influence. These would then have been gradually supplemented by works of distinctly later origin (Jouanna 1999:56-57; Lloyd 1983a:9).

There is evidence that the various manuscripts of Hippocratic writings were collected in Alexandria during the Hellenistic period and 
subjected to critical comparison in an attempt to create a reliable compilation. The first steps in this direction were taken by Baccheius ( $2^{\text {nd }}$ century BC), who collated 23 works. A century later Erotianus included 49 works, and in the $1^{\text {st }}$ century AD Celsus considered 25 texts to be genuinely Hippocratic, while in the $2^{\text {nd }}$ century AD the influential physician-author Galen compiled yet another collection of Hippocratic texts (Jouanna 1999:63; Levine 1954:19, 77; Lloyd 1983a:54). The exact number of texts in the Corpus thus varies in accordance with the various scholars' opinions on their authenticity.

In its original Greek (with certain partial translations into Arabic) the Corpus Hippocraticum remained the basis of medical training for two millennia. Between 1831 and 1860 Emile Littré translated the entire oeuvre into French (ten volumes), making it more accessible to the European community. The Loeb translations of most of the texts into English followed. This led to increased interest in and critical assessment of the Corpus, particularly in terms of debating which works could be viewed as authentic emanations from the Hippocratic School and which as written by Hippocrates himself (Jouanna 1999:56). The most sceptical of modern scholars was probably Edelstein, who pronounced in 1931 that there is no demonstrable link whatsoever between Hippocrates and the Corpus Hippocraticum (Edelstein 1967a:133-144).

\subsection{Compilation}

All but four of the 69 works which, according to Jouanna (1999:5671), comprised the Corpus, deal with medicine. The four are mainly biographical works describing incidents from Hippocrates's life. Three date from the Hellenistic period (from the late $4^{\text {th }}$ century BC onwards): Speech from an altar, Decree from Athens, and Speeches of a delegate; while Letters, supposed to have been by Hippocrates himself, was actually probably written in the $1^{\text {st }}$ century AD.

As far as can be ascertained, 47 of the 65 medical works date from the Hippocratic era ( $5^{\text {th }}$ and $4^{\text {th }}$ centuries BC), eight from the Hellenistic era, and seven from the Christian period (from the $1^{\text {st }}$ century AD onwards). 57 of the works were probably compiled by "Hippocratic physicians" (often in joint authorship), 21 of these having emanated from the community at Cos. Six texts (Internal diseases, Diseases of women 
II, Diseases I, II and III, and Affections) were partially or completely written by Cnidian physicians (Gillespie 1972:420; Jouanna 1999:6671; Levine 1954:19).

Although all the texts were written in the Ionian dialect, this does not mean that the authors were all from Ionia (the western coast of Asia Minor and the surrounding islands, such as Cos). Ionia was indeed the area in which medical knowledge was documented for the first time in the $5^{\text {th }}$ century BC, but the Greek tradition was to use the dialect of the first work in any specific genre for all subsequent works in that genre. This explains why all later medical writers would have used the Ionian dialect, even if they came from different parts of the Greek world.

It is thus generally accepted that the original nucleus of the Corpus was compiled mainly by a corps of Hippocratic physicians during the $5^{\text {th }}$ and $4^{\text {th }}$ centuries $\mathrm{BC}$, but that there were many later additions of varying quality. It is impossible to tell for certain which works (if any) were written by Hippocrates himself, but experts have identified certain texts as likely to represent his personal contribution. Littré believed that twelve texts were genuinely authored by Hippocrates, but today fewer than half of those would pass muster. Based on comments made by contemporaries, it is suggested that Prognosis, On joints, On fractures, and Epidemics $I$ and $I I$ were written by Hippocrates himself. The nature of the child and The eight-month foetus are ascribed to his son-in-law, Polybus. Another group of texts is clearly by a single author, but his name is unknown; examples include The sacred disease, Airs, waters and places, Diseases IV, Generation/The nature of the child, Fistulae, Haemorrhoids, Prognostics I and II, Epidemics II, IV, V, VI and VII, and Humours (Gillespie 1972:420; Jouanna 1999:59-68).

The Corpus pays relatively little attention to what we would term anatomy and physiology (which are covered only in Anatomy, The heart, and Parts of the buman body), and contains several surveys of the pathogenesis of disease founded on the theory of the humours (Humours, Nutriment, Breaths, and The nature of man), but as a whole it contains outstanding clinical contributions based on detailed questioning and examination of patients, taking cognisance of relevant aspects of the environment (Aphorisms, Airs, waters and places, Diseases I-IV, Epidemics 
I-VII and Prognostics). Specific attention is paid to surgical and orthopaedic conditions (On fractures, On joints, Haemorrhoids, Fistulae, In the surgery) as well as to gynaecology and embryology (Diseases of women I and II, Generation/The nature of the child, and The nature of women), to paediatrics (Diseases of girls, Teeth) and to general therapy, where the emphasis is not so much on medication as on a healthy lifestyle ( $R e-$ gimen, Regimen in acute diseases and The use of liquids). Epilepsy is described in the classic text The sacred disease, and afflictions of the eye in Sight. The Corpus Hippocraticum is particularly famous for its emphasis on professionalism and medical ethics (Decorum, The law, Physician, Precepts, The art), for its dismissal of superstition and inapplicable philosophical views (Ancient medicine), as well as for the establishment of a professional code for physicians, the "Hippocratic Oath" (Gillespie 1972:420-424; Jouanna 1999:47-71; Levine 1954:19).

The contents of the collection are thus very diverse, while the texts vary in length from a single page to several volumes. No unity in terms of form, intention or target group links the various works in the Corpus - indeed, they differ fundamentally on certain key aspects of medicine, for example the number and nature of the humours. To judge by the texts, the Hippocratic authors were mainly practising doctors who wrote "textbooks" in order to improve therapy, rather than from an academic desire to add to the sum of knowledge. Their views were based on observation rather than on abstract reasoning. However, because human cadavers were not dissected (except by the Alexandrian doctors Herophilus and Erasistratus in the $3^{\text {rd }}$ century BC), since dissection only became normal practice in the $19^{\text {th }}$ century, their knowledge of human anatomy and physiology was limited and sometimes inaccurate (Lloyd 1983b:27, 113).

\subsection{The Hippocratic Oath}

This striking document, probably the most famous work in the Corpus Hippocraticum, was almost certainly composed in the time of Hippocrates, but also contains later additions. It comprises two parts - an agreement between student and teacher (in which the student undertakes, among other things, to honour his teacher as he does his parents, to support him financially and to train his sons free of charge), and a code of ethical conduct. In terms of this code the student promises 
to treat his patients with respect and to the best of his ability; to keep confidential anything he hears in his professional capacity, even if it is unrelated to the case; not to administer any poison or to bring about an abortion; to practise only those modalities of treatment which are within his capabilities, leaving surgical procedures, in particular, to those trained to perform them; to lead a virtuous life, and not to engage in sexual intercourse with his patients (Jouanna 1999:47; Edelstein 1967b:20-39).

The Oath is traditionally viewed as a product of the School of Cos, but experts have shown that its philosophical background is far stricter than the prevailing medical policy of the time, which (among other things) condoned abortion, did not condemn euthanasia by means of poison, and permitted certain surgical operations. It has thus been argued that the Oath is in essence a Pythagorean document. Followers of Pythagoras ( $6^{\text {th }}$ century BC) lived by a strict philosophy of life, condemning abortion and any form of poisoning, disparaging surgery, refraining from loose speech, and maintaining a strict code of responsibility towards their teachers. Edelstein (1967b:20-39) thus contends that what was originally a Pythagorean manifesto, perhaps unpopular and even differently worded, gained great popularity with the dawn of the Christian era and was then recast into its present state. However, his suggestion that a piece of far stricter, "foreign" philosophy would have been incorporated into the writings of the Hippocratic community appears strange. The Oath appears in its present form as early as the Corpus compiled by Erotianus ( $1^{\text {st }}$ century BC).

According to Jouanna (1999:42-52), students entering the medical profession from outside the Asclepiadae family were required to take the Oath in order to conclude a viable contract with the teacher (at a set rate), and to bind themselves to ethical conduct. The children of the Asclepiadae were exempt, and studied free of charge. This use of the Oath was apparently instituted when it was decided to extend medical training beyond the Asclepiadae family itself. It would appear that this decision was taken on Cos at the time when the Asclepiadae family died out on the neighbouring island, Rhodes, thus eliminating any possibility of medical training there. 


\section{CONCLUSION}

Lloyd (1983a:59) makes the interesting point that while Aristotelian physics, Ptolemaic astronomy and Galenic medicine were replaced by new modes of thought after the Renaissance, the legacy of Hippocrates retained a place of honour - indeed, he was singled out as a norm by $16^{\text {th }}$ - and $17^{\text {th }}$-century medical pioneers such as Boerhaave and Sydenham. As was the case with Galen, the new medical science identified the errors of the ancient anatomy, physiology and pathogenesis of disease contained in the Corpus Hippocraticum, but unlike him, the new generation considered Hippocrates's clinical medicine, his fundamentally investigative approach and his insistence on both scientific thought and ethical professionalism to transcend time, and continued to practise it with respect. In the same way as Homeric verse rang in a new tradition of poetry in Western literature, the Hippocratic texts may be seen as representing the very beginnings of rational medicine, and as part of the advent of science in the Golden Age of Greece. Despite its many flaws, the Hippocratic practice of medicine was so fundamental that its message has stood the test of time and remains inspirational even today.

The most important contribution of Hippocratic medicine was surely that — to a great extent — it made a break with the superstition and magical thought of the previous age, in order to introduce a medical practice which was rational, based on what was accepted at the time as scientific fact. Because medical science was so poorly understood, though, it may be more accurate to speak of it as pre-scientific rational medicine. With all its flaws, however, this genuine attempt at scientific medical practice was so successful that it was not displaced by any better system for 2000 years, and retains a significant degree of acceptability even today (Gillespie 1972:429).

As has been indicated, relatively little is known of Hippocrates as a historical personage. By separating the considerable legendary and unproven components of the traditional version of his life from the probable and the proven, we emerge with a picture of an outstanding ancient physician who, while he definitely could not have penned the entire Corpus Hippocraticum (possibly only five of the almost 70 texts), and was not the object of undue adulation in his own time, did apparently succeed in establishing a remarkable culture of scientific and 
ethical practice, as well as in inspiring his students to such an extent that their pupils too continued to honour and emulate his thought through many ages. It was these "Hippocratic physicians" (first in Cos, then in Thessaly and elsewhere) who, stimulated by the zeal of their teacher, assembled the famous collection of medical texts. Most of these were written during or shortly after Hippocrates's time, but additions were still being made to the Corpus even in the Christian era. Although the views expressed are sometimes contradictory and some of the texts may even be viewed as apocryphal, the otherwise heterogeneous collection is unified by the fact that it represents a sincere attempt to describe as precisely as possible everything the physicians observed, with the aim of affording more assistance to future physicians.

The greatest gift of the Hippocratic legacy to modern medicine lies in its historical contribution - the transmission of pre-Socratic and pre-Aristotelian medical thought from the Golden Age of Greece (the $5^{\text {th }}$ century BC) and the period immediately afterwards - and in its uniquely timeless vision of ethical practice. These ethical values are encapsulated in the Hippocratic Oath, which insists on a practice founded on morality and science, dedicated service to and respect for patients - a culture which has remained valid in essence despite changing views on aspects such as surgical procedures or a student's responsibility towards his or her teacher. For the practitioner of today, the Hippocratic authors' clinical approach (i.e. their exhaustive questioning and examination of patients, taking cognisance of any psychological or environmental factor which may play a role in disease, and their emphasis on maintaining a healthy lifestyle rather than being dependent on unproven medications) still represents the essence of what is eternally relevant in the practice of the medical profession. 


\section{REFERENCES}

ARISTOTLE

1959. Politics (transl. H. Rackham). London: W. Heinemann Loeb Classical Library Vol. XXI.

\section{EDELSTEIN L}

1967a. The genuine works of Hippocrates. In: O. Temkin \& C. L. Temkin (eds.), Ancient medicine. Selected papers of Ludwig Edelstein (Baltimore \& London: The Johns Hopkins University Press), pp. 133-44.

1967b. The Hippocratic oath: text, translation and interpretation. In: O. Temkin \& C.L. Temkin (eds.), Ancient medicine. Selected papers of Ludwig Edelstein (Baltimore \& London: The Johns Hopkins University Press), pp. 3-64.

\section{GALEN}

1997. The best doctor is also a philosopher. In: Galen Selected works (transl. P.N. Singer). Oxford \& New York: Oxford University Press.

Gillespie C C (ED.)

1972. Dictionary of scientific biography. Vol. VI. New York: Charles Scribner's Sons.

JOUANNA J

1999. Hippocrates (transl. M.B. de Bevoise). Baltimore \& London: Johns Hopkins University Press.

\section{LEVINE E B}

1954. Hippocrates. New York: Twayne Publishers.

\section{LLOYD G E R}

1983a (1950). Hippocratic writings. Penguin Books.

1983b. Science, folklore and ideology. Studies in the life sciences in ancient Greece. London: Oxford University Press.

\section{PINAULT J R}

1992. Hippocratic lives and legends. Leiden: E. J. Brill.

\section{PLATO}

1924. Laches. Protagoras. Meno. Euthydemus (transl. W. R. M. Lamb). London: W. Heinemann Ltd. Loeb Classical Library Vol. II.

1960. Euthyphro. Apology. Crito. Phaedo. Phaedrus (transl. H. N. Fowler). London: W. Heinemann. Loeb Classical Library Vol. 1.

\section{VARRO}

1934. Marcus Porcius Cato. On agriculture. Marcus Terentius Varro. On agriculture (transl. W. E. Hooper \& H. B. Ash). London: W. Heinemann. Loeb Classical Library. 